\title{
Circulating Resistin and Visfatin Levels in Patients with Inflammatory Bowel Disease as Predictors of Treatment Response
} \author{
Labib $^{3}$ \\ Corresponding Author \\ Jihan A. Shawky \\ Mobile: \\ $+20111950071$ \\ E mail: \\ jihan.shawky2013@ya \\ hoo.com \\ Key word: Resistin; \\ Visfatin; inflammatory \\ bowel disease \\ Background and study aim: Ulcerative \\ colitis (UC) and Crohn's disease (CD) are \\ the common forms of inflammatory \\ bowel disease (IBD). The etiology and \\ pathogenesis are not fully understood yet. \\ Many studies have been focused on \\ adipokines in the pathogenesis of IBD. \\ IBD is associated with alteration in fat \\ distribution and development of white \\ adipose tissue (WAT) hypertrophy in the \\ mesentery. Most of adepokines are \\ formed in WAT or in immune cells and \\ play an important role in IBD \\ manifestations. The aim of this study was \\ to evaluate the levels of resistin and \\ visfatin in IBD patients before and after \\ treatment. \\ Patients and Methods: 40 patients with \\ IBD who(15 patients with $\mathrm{CD}$ and 25 \\ patients with UC) attended to Tropical \\ Medicine and Internal Medicine \\ Departments; Zagazig University
}

Jihan A. Shawky ${ }^{1}$, Hosam M. Dawod ${ }^{1}$, Hesham A. Atia ${ }^{2}$, Hany A.

${ }^{1}$ Department of Tropical Medicine, Faculty of Medicine, Zagazig University, Egypt

${ }^{2}$ Department of Internal Medicine Faculty of Medicine, Zagazig University, Egypt

${ }^{3}$ Department of Clinical Pathology Faculty of Medicine, Zagazig University, Egypt

\section{INTRODUCTION}

Inflammatory bowed disease (IBD) is inflammatory condition of small intestine and the colon. Ulcerative colitis (UC) and Crohn's disease (CD) are the most common two forms $[1,2,3]$.

The pathogenesis of IBD is still not clear, it is thought that it is a result of genetic predisposition or immune response of the gut to its commensal bacteria [4], also the role of lifestyle and other factors as non steroidal anti-inflammatory drugs [5], smoking [6] or recent appendectomy [7]. Recent studies have been focused on pro-inflammatory cytokines and circulating adipokine levels $[8,9]$.

Inflammatory bowel disease (IBD) is associated with changes in fat distribution and fat mass as increasing visceral fat mass and development of white adipose tissue (WAT) [10] and subcutaneous adipose tissue [11].
Hospitals from March 2012 till December 2013 were included in this study. Serum levels of resistin and visfatin were measured before treatment and 3 months after the treatment.

Results: The mean serum levels of resistin in Crohn's disease ranged from $12.2+2 \mathrm{ng} / \mathrm{ml}$ to $9.0+4.0(\mathrm{P}=0.1)$ and the mean serum levels of visfatin in Crohn's disease ranged from $5.6+4.6 \mathrm{ng} / \mathrm{ml}$ to $3.4+4.1 \mathrm{ng} / \mathrm{ml}(\mathrm{P}=0.04)$ before and after treatment respectively, and the mean serum levels of resistin in ulcerative colitis ranged from $11.2+2 \mathrm{ng} / \mathrm{ml}$ to $7.5+3.1 \mathrm{ng} / \mathrm{ml}(\mathrm{P}=$ 0.039 ) and the mean serum levels of visfatin in ulcerative colitis ranged from $3.7+1.2$ to $2.5+1.1 \mathrm{ng} / \mathrm{ml} \quad(\mathrm{P}=0.004)$ before and after treatment respectively.

Conclusion: The serum levels of resistin and visfatin decreased significantly after treatment induction for IBD, so can be used as a marker for treatment success.

Most of adipokines are formed in WAT or in immune cells play an important role in IBD pathogenesis $[12,13]$.Resistin is one of the cysteinerich proteins family, it was described as adipocyte-derived mediator of hepatic insulin resistance [14], it is produced by mononuclear cells [15], and minimal amount is produced by visceral adipose tissue [16]. Resistin has pro-inflammatory properities as it induces the production of IL- 6 , IL-1B and TNF- $\alpha$ from monocyte $[17,18]$, it is observed to be elevated in patients with IBD [19].

Visfatin is adipokine identified in visceral adipose tissue, its structure is identical to pre-B-cell colony-enhancing factor (PBEF) [20], its level is higher in obese women compared to normal weight [21], the main source of visfatin is WAT-derived macrophages and stromal vasculature [22,23]. Visfatin has pro-inflammatory properties as 
induction of TNF- $\alpha$, IL- 6 , IL- 8 by peripheral mononuclear cells $[24,25]$. Visfatin elevation has been observed in IBD and can be attributed to be a causative factor of decreased bone mass density in IBD $[26,27]$.

The aim of this study was to evaluate the levels of resistin and visfatin in IBD patients before and after treatment.

\section{PATIENTS AND METHODS}

Forty patients with active IBD admitted to Tropical Medicine and Internal Medicine Departments, Zagazig University Hospitals, Egypt (age range from 20 to 43 years old) were enrolled.

Activity of Crohn's disease evaluated by $\mathrm{CD}$ activity index score [28], while activity in UC according to Robert et al [29].

\section{Exclusion criteria:}

Hypothyroidism or hyperthyroidism

Diabetes mellitus

Adrenal failure

Hyperlipidemia

\section{COPD}

Autoimmune disease

All patients were subjected to the following:

- Full history taking.

- Thorough clinical examination.

- Complete blood picture.

- Liver function test.

- C-reactive protein (CRP).

- Erythrocyte sedimentation rate.

- Colonoscopy and biopsies for histopathology.

- Serum level of visfatin and resistin were measured by ELISA using a commercially available kit (BioVision Research Products, Mountain View, USA) And (Linco Research, St. Charles, MO,USA) respectively before induction of treatment and 3 months after treatment .

- Informed consent was obtained from all patients and the study was approved by our Institutional Review Board.

\section{Statistical analysis:}

All data were expressed as mean and standard deviation. For quantitative data (normally distributed) comparison between two groups was done using student t-test $(\mathrm{p}<0.05$; significant). All statistical calculations were done using SPSS (Statistical Package for the Social Science; SPSS Inc., Chicago, IL, USA) version 15 for Microsoft Windows.

\section{RESULTS}

Patients were matched for age, sex. Colonoscopy and biopsy divided the patients to 10 patients with CD and 25 patients with UC with follow up loss of 4 cases and one case need surgical intervention.

The mean serum levels of resistin in Crohn's disease ranged from $12.2+2 \mathrm{ng} / \mathrm{ml}$ to $9.0+4.0$ $(\mathrm{P}=0.1)$ and the mean serum levels of visfatin in Crohn's disease ranged from $5.6+4.6 \mathrm{ng} / \mathrm{ml}$ to $3.4+4.1 \mathrm{ng} / \mathrm{ml} \quad(\mathrm{P}=0.04)$ before and after treatment respectively, and the mean serum levels of resistin in ulcerative colitis ranged from $11.2+2 \mathrm{ng} / \mathrm{ml}$ to $7.5+3.1 \mathrm{ng} / \mathrm{ml}(\mathrm{P}=0.039)$ and the mean serum levels of visfatin in ulcerative colitis ranged from $3.7+1.2$ to $2.5+1.1$ $\mathrm{ng} / \mathrm{ml}(\mathrm{P}=0.004)$ before and after treatment respectively. 
Table (1): Patients and disease characteristics

\begin{tabular}{|c|c|c|}
\hline & $\mathbf{C D}(\mathbf{N}=\mathbf{1 0})$ & $\mathbf{U C}(\mathbf{N}=\mathbf{2 5})$ \\
\hline Age (years) & $35 \pm 9$ & $40 \pm 4$ \\
Mean +SD & & 18 \\
\hline Gender & 3 & 6 \\
Male & 7 & \\
Female & & 25 \\
Treatment & 8 & 24 \\
5 ASA & 7 & 8 \\
Steroid & 8 & 0 \\
Azathioporine & 1 & \\
Infliximab & & \\
\hline
\end{tabular}

CD, Crohn's disease; UC, Ulcerative colitis.

Table (2): Serum level of resistin and visfatin in CD before and after treatment

\begin{tabular}{|l|c|c|c|}
\hline \multicolumn{1}{|c|}{ CD } & Before treatment & After treatment & P \\
\hline S. Resistin & $12.2 \pm 2 \mathrm{ng} / \mathrm{ml}$ & $9.0 \pm 4.0 \mathrm{ng} / \mathrm{ml}$ & 0.01 \\
S. Visfatin & $5.6 \pm 4.6 \mathrm{ng} / \mathrm{ml}$ & $3.4 \pm 4.1 \mathrm{ng} / \mathrm{ml}$ & 0.04 \\
C. reactive protein & $6 \pm 1.5 \mathrm{mg} / \mathrm{dl}$ & $0.5 \pm 0.4 \mathrm{mg} / \mathrm{dl}$ & $<0.01$ \\
\hline
\end{tabular}

Significant decrease in serum levels of visfatin with decrease in resistin and $\mathrm{C}$. reactive protein in Crohn's disease after treatment.

Table (3) : Serum level of resistin and visfatin in UC before and after treatment

\begin{tabular}{|l|c|c|c|}
\hline \multicolumn{1}{|c|}{ UC } & Before treatment & After treatment & P \\
\hline S. Resistin & $11.2 \pm 2 \mathrm{ng} / \mathrm{ml}$ & $7.5 \pm 3.1 \mathrm{ng} / \mathrm{ml}$ & 0.039 \\
S. Visfatin & $3.7 \pm 1.2 \mathrm{ng} / \mathrm{ml}$ & $2.5 \pm 1.1 \mathrm{ng} / \mathrm{ml}$ & 0.004 \\
C. reactive protein & $4.5 \pm 0.5 \mathrm{mg} / \mathrm{dl}$ & $0.5 \pm 0.2 \mathrm{mg} / \mathrm{dl}$ & $<0.05$ \\
\hline
\end{tabular}

Significant decrease in serum levels of visfatin with decrease in resistin and $\mathrm{C}$. reactive protein in ulcerative colitis after treatment. 

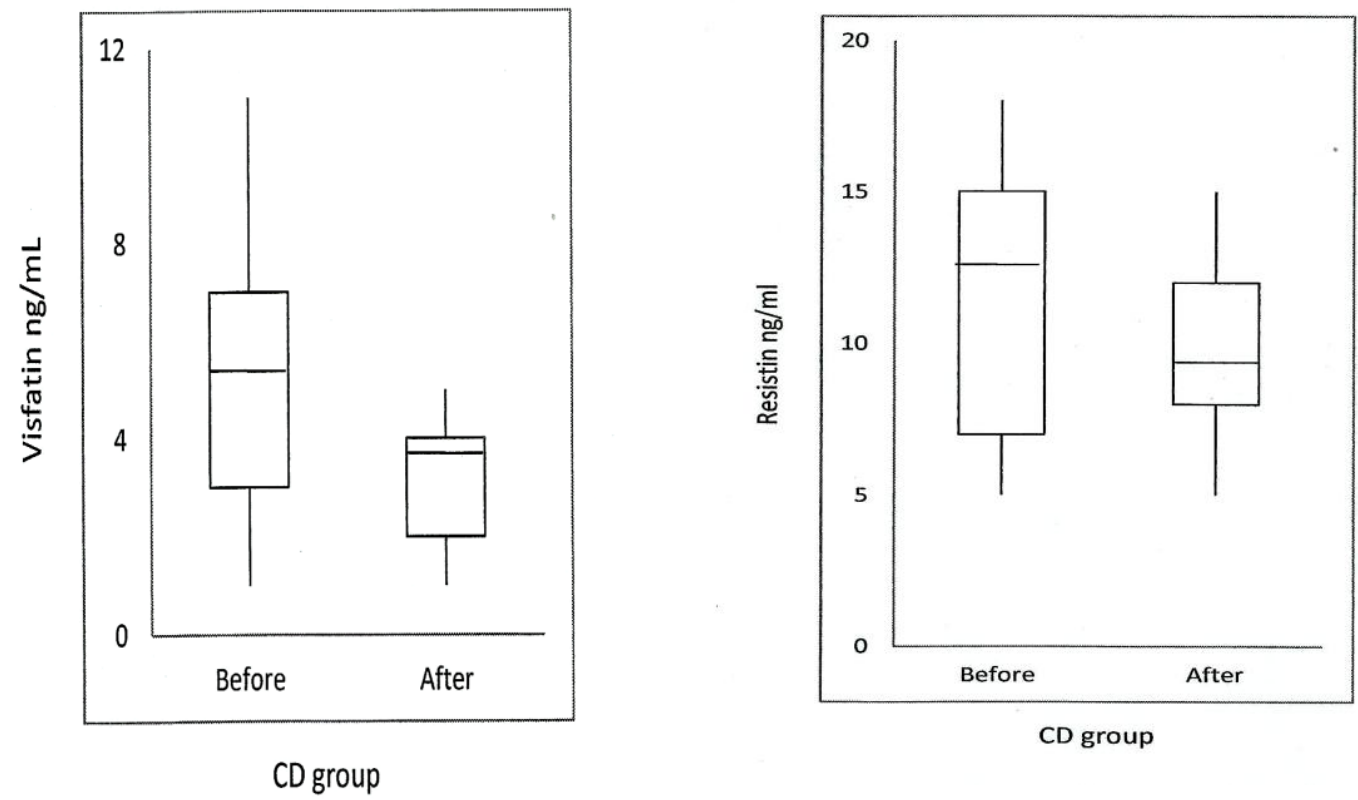

Figure (1): Serum levels of visfatin and resisitin in Crohn's disease before and after treatment.
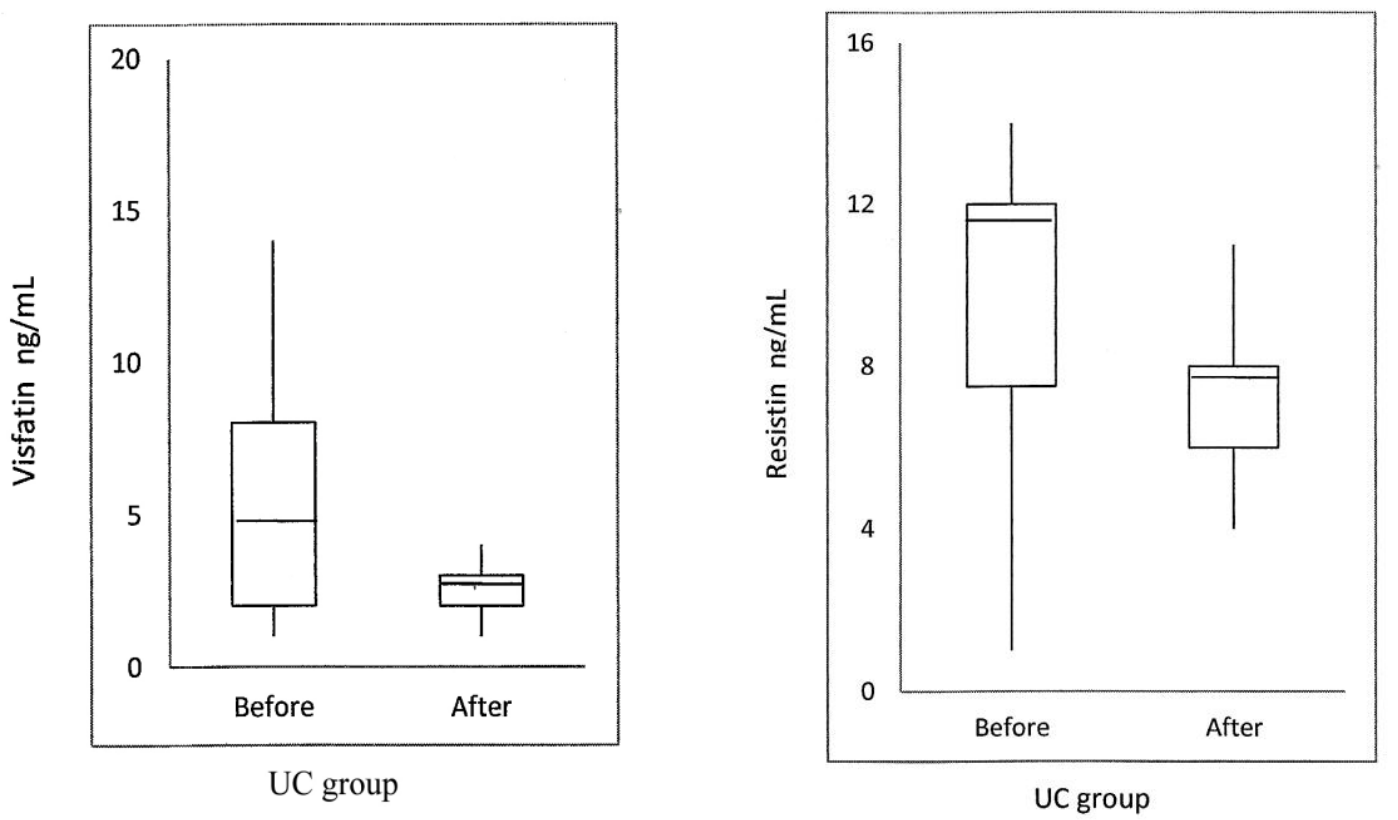

Figure (2): Serum levels of visfatin and resisitin in Ulcerative Colitis before and after treatment. 


\section{DISCUSSION}

In the current study, we measured the circulating levels of two adipocytokines in patients with active IBD before and after induction of treatment by three months, which are produced by WAT and they are closely related to chronic inflammation, a fact that may implicate them in pathogenesis and follow up of the response to medical treatment.

In our study, both resistin and visfatin have a significantly lower circulating levels after 3 months of induction of treatment of active UC and $\mathrm{CD}$ patients as compared with levels before treatment $(\mathrm{P}=0.01$ and $\mathrm{P}=0.04$ respectively in $\mathrm{CD}$ patients and $\mathrm{P}=0.039$ and $\mathrm{P}=0.004$ respectively in UC patients, these results are inconsistence with Young et al. [30] who found that visfatin serum level decreased significantly $(\mathrm{P}=0.046)$ after induction therapy suggesting as a marker of successful therapy, whereas, the serum level of resistin showed no significant alteration after treatment or significant correlation with changes in CRP or clinical indices and this may be explained by shorter duration in their study 10 weeks than in this study (12w) which may give more time for obvious significant changes.

In other study, Valenkin et al. [19] found that both resistin and visfatin were increased in active disease group not in those in remission denoting the effect of treatment and the mean serum resistin and visfatin were $12.2 \pm 2 \mathrm{ng} / \mathrm{ml}$ in $\mathrm{CD}$ patients and $11.2 \pm 2 \mathrm{ng} / \mathrm{ml}$ in UC patients before treatment and this was not in concordance with results obtained by Kostantinos et al. [31] who showed higher levels and this could be explained by larger number of patients and the importance of value of decrease not the one time value itself.

The CRP showed significant decrease after treatment in both $\mathrm{CD}$ and UC patients $(\mathrm{P}<0.01$ and $\mathrm{P}<0.02$ respectively) and this result is matching with that of Young et al. [30] and these results of resistin, visfatin and CRP increase their importance as possible marker for treatment response and for follow up after induction treatment.

\section{CONCLUSION}

The serum levels of resistin and visfatin decreased significantly after treatment induction for IBD, so can be used as a marker for treatment.
Funding: None.

Conflicts of interest: The authors declare no conflict of interest.

\section{Ethical approval: Approved.}

\section{REFERENCES}

1. Baumgart DC, Carding SR, IBD : Cause and immunobiology.. Lancet 2007; 369 : 1627-40.

2. Baumgart DC, Carding SR. IBD, clinical aspect and established and evolving therapies. Lancet 2007; 369 (9573): 1641-57.

3. Xavier RJ, Podolsky DK. Unraveling the pathogenesis of IBD. Nature 2007; 448 (7152):427-34.

4. Heap Ga, Van Heel DA. The genetic of chronic inflammatory diseases. Hum Mol Genet. 2009; 18 : R101-106.

5. Bjarnson I, Zanelli G, Smith T, Prouse P, Williams $P$, Smethurst $P$ et al. Non-steroidal antiinflammatory drug-induced intestinal inflammation in humans. Gastroenterology 1987; 93: 480-89.

6. Odes HS, Pich A, Reif S, Halak A, Lavy A, Keter $\mathrm{D}$ et al. Effects of current cigarette smoking on clinical course of Crohn's disease and ulcerative colitis. Dig Dis Sci 2001,46 : 1717-21.

7. Frisch M, Johansen C, Mellemkiear L, Engels EA, Gridley G, Biggar RJ et al. Appendectomy and subsequent risk of inflammatory bowel diseases. Surgery $2001 ; 130: 36-43$.

8. Olszanecka-Clinanowics M, Chudek J, Kocelak P, Szromek A, Zahorska-Markiewicz B. Body fact changes and activity of tumor necrosis factor system - a 5 year follow up study. Metabolism 2011;60 : 531-36.

9. Olszanecka-Glinianowicz M, Zahorska-Markiewicz B, Janowska J, Zurakowski A. Serum concentrations of nitric oxide, tumor necrosis factor (INF)-alpha and TNF-soluble receptors in women with overweight and obesity. Metabolism 2004;53: 1268-73.

10. Desreumaux P, Ernst O, Geboes K, Gambies L, Berrebi D, Muller-Alouf $\mathrm{H}$ et al. Inflammatory alterations in mesenteric adipose tissue in Chrons disease. Gastroentrology 1999;117(1): 73-81

11. Valentini L, Buning C, Hengstermann S, Schaper L, Koernicke T, Norman K et al. Malnutrition and impaired muscle strength in patients with Crohns disease and ulcerative colitis in remission. Nutrition 2008;24(7-8):694-702

12. Mattacks CA, Sadler D, Pond CM. The cellular structure and lipid/ protein composition of adipose tissue surrounding chronically stimulated lymph nodes in rats. $J$ Anat 2003;202:551-61. 
13. Gambero A, Marostica M, Abdalla Saad MJ Pedrazzoli J Jr. Mesenteric adipose tissue alterations resulting from experimental reactivated colitis. Inflamm Bowel Dis 2007;13: 1357-64.

14. Steppan CM, Bailey ST, Bhat S, Brown EJ, Banerjee RR, Wright CM et al. The hormone resistin links obesity to diabetes. Nature 2001;409 : 307-12.

15. Patel L, Buckels AC, Kinghorn IJ, Murdock PR, Holbrook JD, Plumpton $\mathrm{C}$ et al. Resistin is expressed in human macrophages and directly regulated by PPAR gamma activators. Biochem Biophys Res Commun 2003;300: 472-76.

16. Savage DB, Sewter CP, Klenk ES, Segal DG, Vidal-Puig A, Considine RV et al. Resistin/Fizz 3 expression in relation to obesity and peroxisome proliferators-activated receptor-gamma action in humans. Diabetes 2001;50:2199-202.

17. Bokarewa M, Nagaey I, Dahlberg L, Smith U, Tarkowski A. Resistin, an adipokine with potent proinflammatory properties. J Immunol 2005;174 : 5789-95.

18. Steppan CM, Lazar MA.The current biology of resistin. J Intern Med 2004;255 : 439-47.

19. Valentini L, Wirth EK, Schweizer U, Hengstermann S, Schaper L, Körnicke T, et al. Circulating adipokines and the protective effects of hyper-insulinemia in inflammatory bowel disease. Nutrition 2009;25: 172-81.

20. Piestrzeniewics K, Luczak K, Komorowski J. Obesity and adiponectin in acute myocardial infarction. Cardiol 2007;14 : 29-36.

21. Zahorska-Markiewicz B, OlszaneckaGlinianowicz M, Janowska J, Kocełak P, SemikGrabarczyk E, Holecki M, et al. Serum concentration of visfatin in obese women. Metabolism 2007; 56: 1131-34.

22. Cural Ca, Wegner V, Sengenes C, Miranville A, Tonus C, Busse R, et al. Macrophages in human visceral adipose tissue: increased accumulation in obesity and a source of resistin and visfatin. Diabetologia 2006;49: 744-47.

23. Varma V, Yao-Borengasser A, Rasouli N, Bodles AM, Phanavanh B, Lee MJ, et al. Human visfatin expression relationship to insulin sensitivity, intramyocellular lipids and inflammation. J Clin Endocrinol Metab 2007;92: 666-72.
24. Chang YC, Chang TJ, Lee WJ, Chuang LM. The relationship of visfatin/ pre-B-cell colonyenhancing factor/ nicotinamide phosphoribosyl transferase in adipose tissue with inflammation, insulin resistance, and plasma lipids. Metabolism 2010;59: 93-99.

25. Dahl TB, Yndestad A, Skjelland M, Øie E, Dahl A, Michelsen A, et al. Increased expression of visfatin in macrophages of human unstable carotid and coronary athero-sclerosis possible role in inflammation and plaque destabilization. Circulation 2007;115: 972-80.

26. Moschen AR, Kaser A, Enrich B, Mosheimer B, Theurl M, Niederegger $\mathrm{H}$, et al. Visfatin an adipocytokine with proinflammatory and immunomodulating properties. $J$ Immunol 2007; 178: 1748-58.

27. Moschen AR, Geiger S, Gerner R, Tilg H. Pre-Bcell colony enhancing factor/NAMPT/ visfatin and its role in inflammation related bone disease. Mutat Res 2011;690: 95-101.

28. Best WR, Becktel JM, Singleton JW, Kern F Jr. Development of a Crohn's disease activity index. National cooperative Crohn's Disease study.Gastroentrology.1976:70:439-444.

29. Langan RC, Gotsch PB, Krafczyk MA, Skillinge DD. Ulcerative Colitis: Diagnosis and Treatment. Am FamPhysician 2007; 76(9):1323-1330.

30. Hwangbo Y, Kim HJ, Shim J, Jang JY, Dong SH, Hokim BU, Chang YW. Change of Circulating Leptin, Adiponectin, Resistin, and Visfatin Level after Treatment of Patients with Active Inflammatory Bowel Disease. Intest Res. 2010;8(2): 151-61

31. Karmiris K1, Koutroubakis IE, Xidakis C, Polychronaki M, Voudouri T, Kouroumalis EA. Circulating levels of liptin, adeponectin, resistin and ghrelin in inflammatory bowel disease Inflamm Bowel Dis. 2006;12: 100-105.

Peer reviewers: Salah Elgamal: Professor and Head of Internal Medicine Departments, Hepatogastroenterology Unit, Mansoura Faculty of Medicine, Egypt. Ahmad Abdel-Razik MD, Tropical Medicine Department, Faculty of Medicine, Mansoura University, Egypt.

Editor: Mohamad Emara, Lecturer of Tropical Medicine and Hepatogastroenterology, Faculty of Medicine, Zagazig University, Egypt. 